مجله :ثزوهشهاى بذر ايران / سال سوم/ شماره دوم/ هوسا

تأثير كيتوزان بر جوانهزنى و صفات بيوشيميايى گياهجه ماريتيغال (Silybum marianum L.) تحت تنش شورى

\author{
مهدى عقيقى شاهوردى "، "، حشمت اميدى ‘، سيد اسماعيل موسوى " \\ ' لدانشجوى دكترى فيزيولوزى كياهان زراعى دانشكده كشاورزى، دانشكاه شاهد تهران

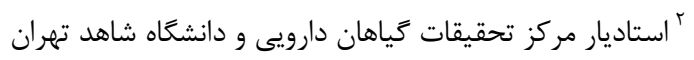

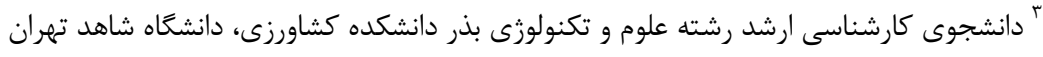

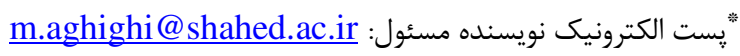

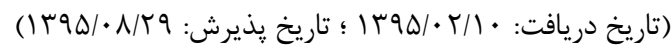

بلهمنظور ارزيابى اثر كيتوزان بر جوانهزنى و برخى ويثزى هاى بيوشيميايى كياه دارويى ماريتيغال در شرايط

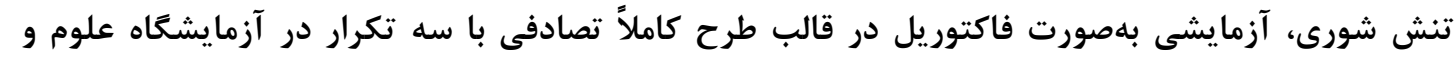

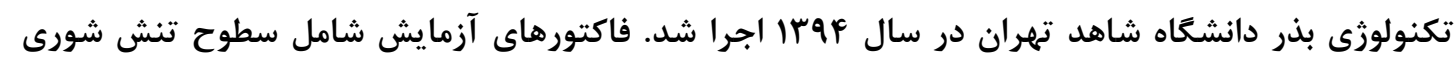

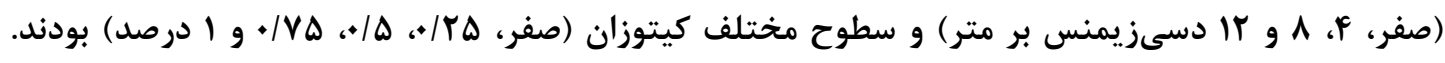
نتايج نشان داد كه تنش شورى موجب كاهش درصد جوانه

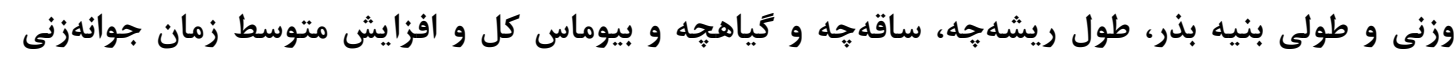

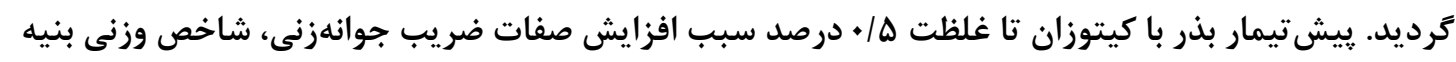

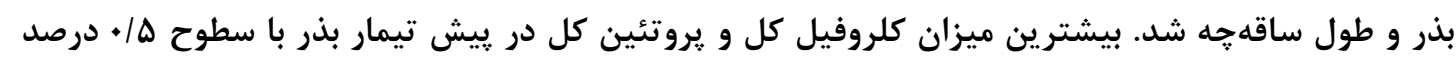

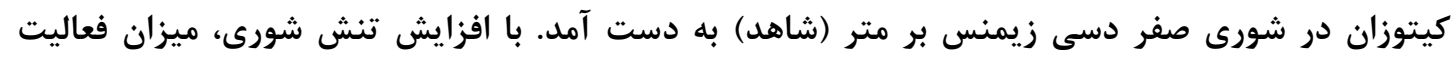

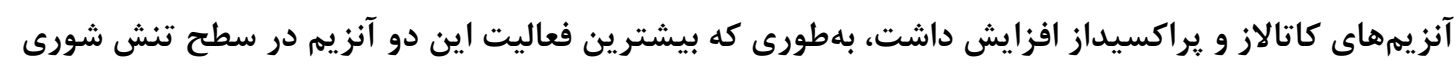

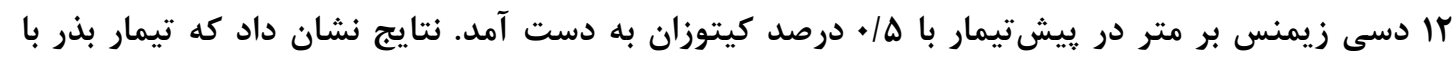

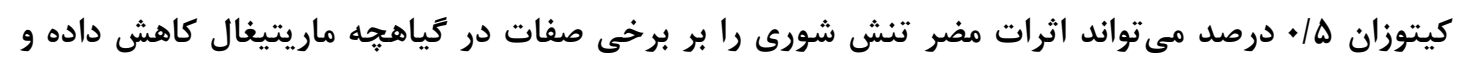

رشد كياهجه را بهبود بخشد.

وازههاى كليدى: بنيه بذر ، يراكسيداز، يروتئين، خارمريم، كاتالاز، كلروفيل

(فرجزاده و همكاران،

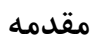

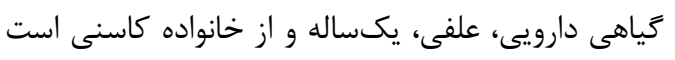

در سالهاى اخير به دليل عوارض جانبى ناشى از

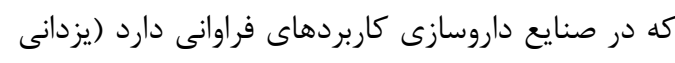

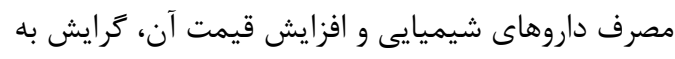

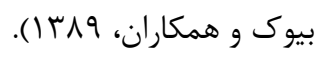

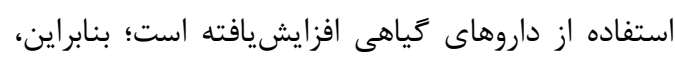

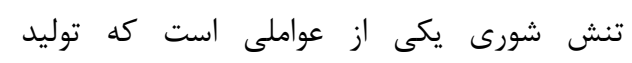

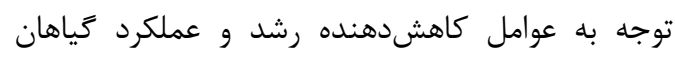

محصولات زراعى را بلهصوص در مناطق خشى و ولى

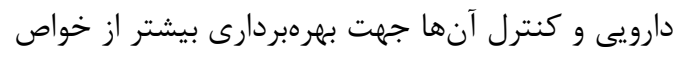

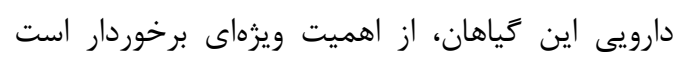

\footnotetext{
${ }^{1}$ Silybum marianum L.
} 
جذب بيشتر مواد غذايى از خاى كمك كرده و بنابراين

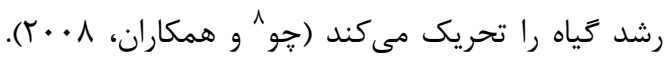

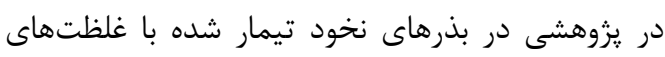

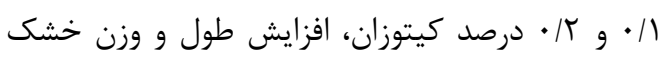

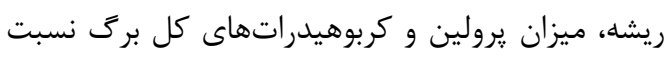

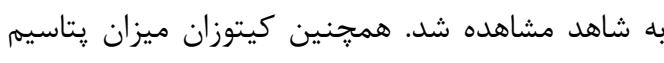

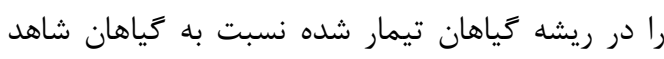

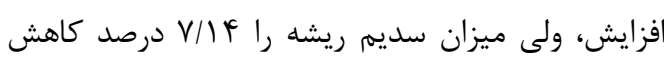

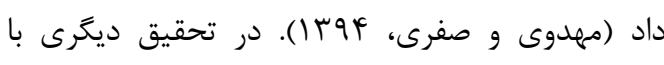

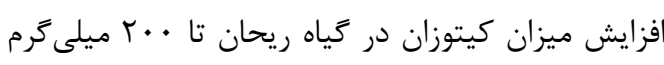

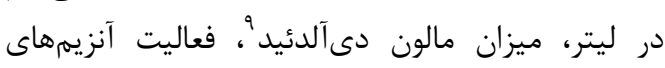

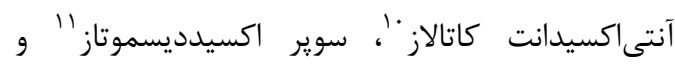

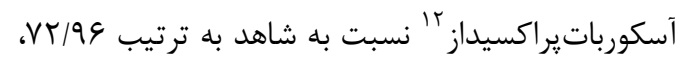
همكاران،

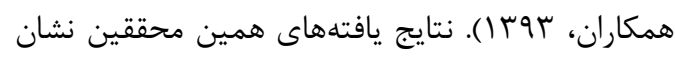

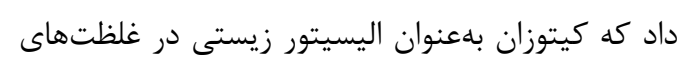

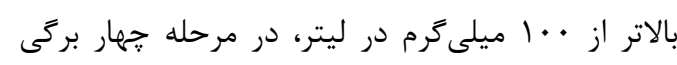

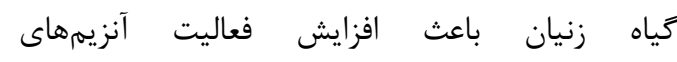

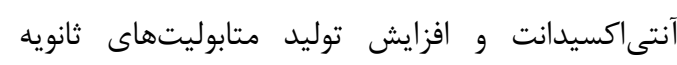

$$
\text { مىشود (نادرى و همكاران، سوسبا). }
$$

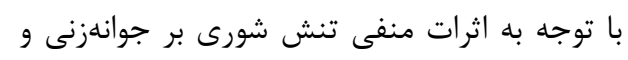

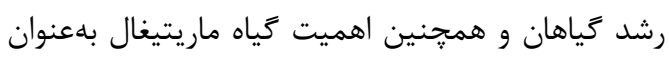

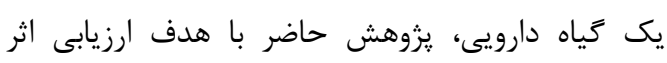
كيتوزان در تعديل اثرات زيانبار تنش شئ شورى داض در مرحله

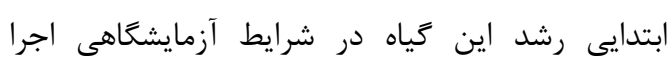

$$
\text { كرديد. }
$$

\section{مواد و روشها}

بامنظور مطالعه تأثير كيتوزان بر خصوصات روات جوانهزنى بذر و و شاخصهاى بيوشيميايى كياهجه

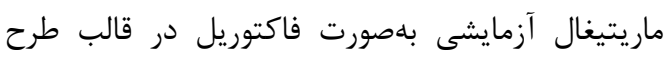

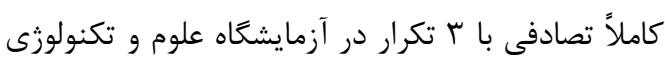

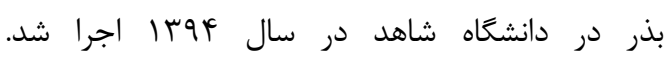
فاكتورهاى آزمايش شامل سطوح مختلف تنش شورى درى

\footnotetext{
${ }^{8}$ Cho

${ }^{9} \mathrm{MDA}$

${ }^{10} \mathrm{CAT}$

${ }^{11} \mathrm{SOD}$

${ }^{12}$ APX
}

نيمه خشك كاهش مى دهد (سرانو' و همكاران، 1999).

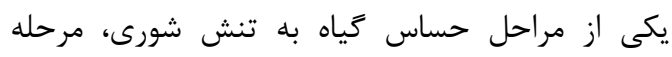

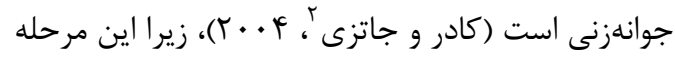

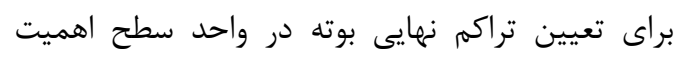

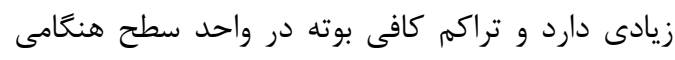

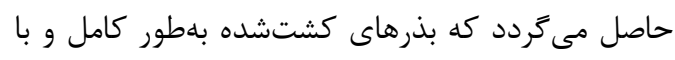

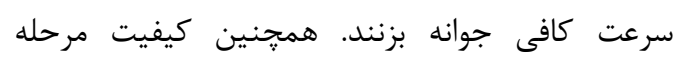
جوانهزنى بذر از نظر كمى و كيفى بر بر عملكرد توليدى

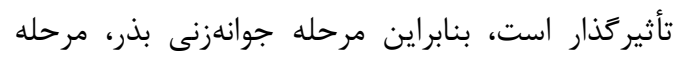
حساس و مهمى است كه با استقرار مطلوب كياهجهنها

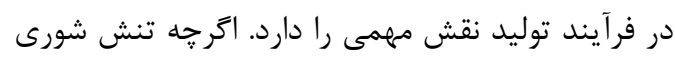

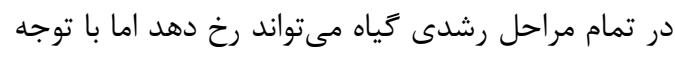

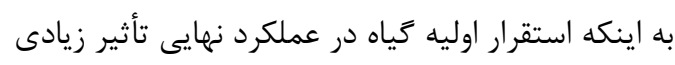

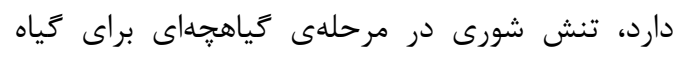

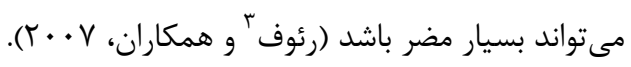
بيش تيمار بذر بلهعنوان يك راهكار جهت افزايش

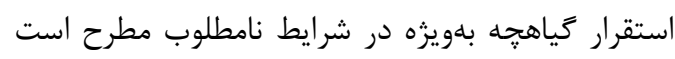

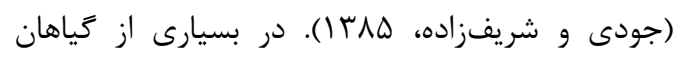

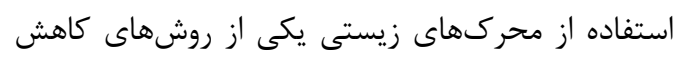

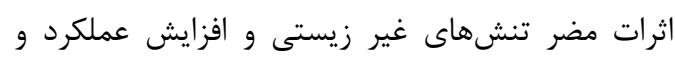

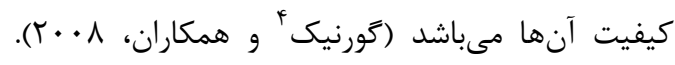

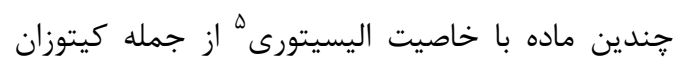

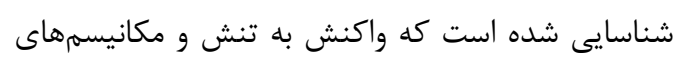
دفاعى را تحريك مى كند (كوالسكى " و و همكاران،

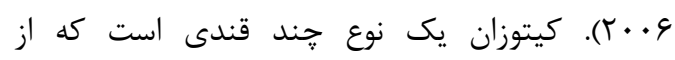

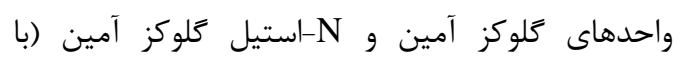

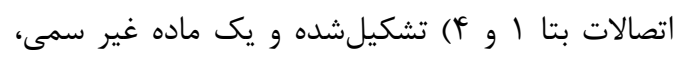

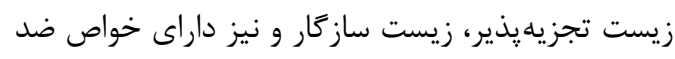

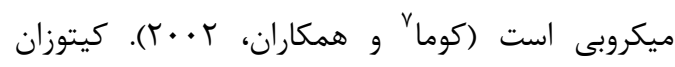

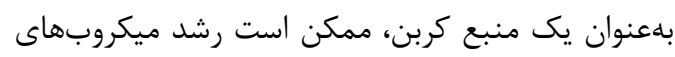

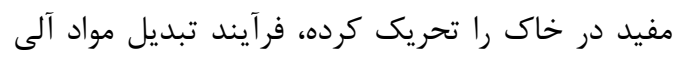

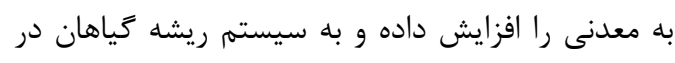

\footnotetext{
${ }^{1}$ Serrano

${ }^{2}$ Kader and Jutzi

${ }^{3}$ Rauf

${ }^{4}$ Gornik

${ }^{5}$ Elicitors

${ }^{6}$ Kowalski

${ }^{7}$ Coma
} 
مجله يثوهش هاى بذر ايران / سال سوم/ شماره دوم/ هوسا

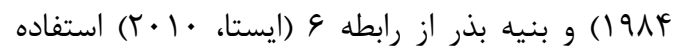
شد.

$\mathrm{GP}=(\mathrm{n} / \mathrm{N}) \times 100$

[رابطه 1)

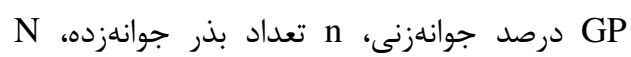
تعداد كل بذر كشتشده

$$
G R=\sum_{i=1}^{n} \frac{n i}{d i}
$$

تما شعاد بذرهاى جوانهزده در هر شمارش، di تعداد

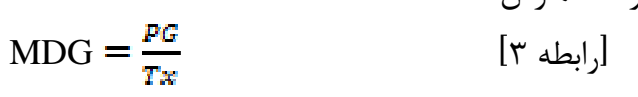$$
\text { درصد جوانهزنى، Tx PG تعداد روزهاى آزمايش }
$$

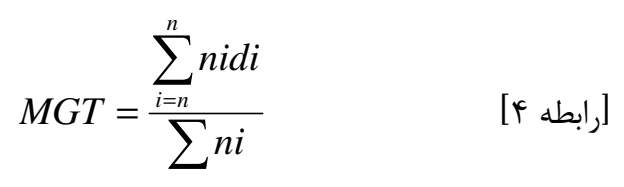

ni ميانگين مدتزمان جوانهزنى، MGT

تعداد بذر جوانهزده در هر شمارش، di تعداد روز تا ميان شمارش

$$
\begin{aligned}
& \mathrm{GC}=\frac{1}{M G T} \times 100 \quad\left[\begin{array}{l}
\Delta \text { ابطه }
\end{array}\right]
\end{aligned}
$$

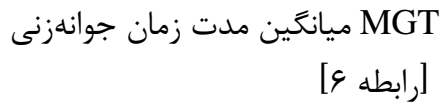

درصد جوانهزنى × طول يا وزن= شاخص طولى يا

$$
\text { وزنى بنيه بذر }
$$

$$
\begin{aligned}
& \text { اندازهَيرى صفات فيزيولوزيكى و بيوشيميايى }
\end{aligned}
$$

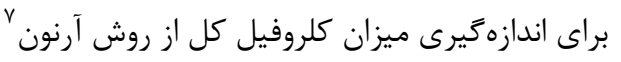

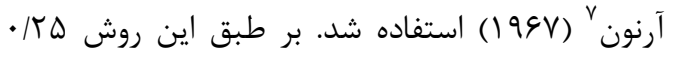

$$
\begin{aligned}
& \text { زرم زياهجه ماريتيغال (برداشتشده در انتهاى آزمايش } \\
& \text { رشد گياهجهاى در داخل ظرف يترى) در هاون جينى }
\end{aligned}
$$

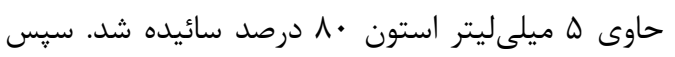

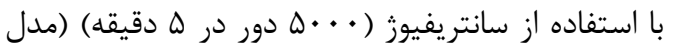

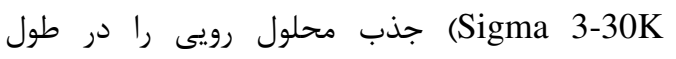

$$
\begin{aligned}
& \text { كلروفيل كل محاسبه گرديد. }
\end{aligned}
$$

Chl a=(12.25 $\times$ A663-2.79 $\times$ A649)

$\mathrm{Chl} \mathrm{b}=(21.21 \mathrm{~A} 646-5.1 \mathrm{~A} 663)$

Chl Total $=\mathrm{Chl} \mathrm{a}+\mathrm{Chl} \mathrm{b}$

\footnotetext{
${ }^{7}$ Arnon
}

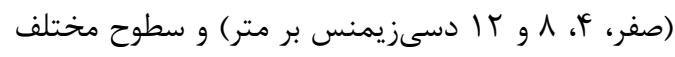

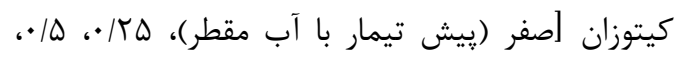

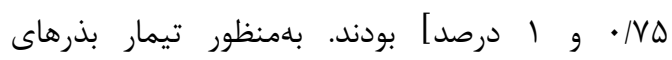

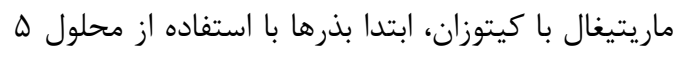
درصد هييوكلريتسديم به مدت · مات دقيقه ضدعفونى شده و سيس در غلظتهاى مختلف محلولهاى كيتوزان (تهيه محلولهاى كيتوزان با غلظتهاى موردنظر با اسيد استيك يك درصد صورت گرفت) و آب مقطر (براى تيمار شاهد) به مدت r ساعت در دماى له در درجه سانتى گراد غوطهور شدند (نادرى و همكاران، سوبار (ا). تعداد • F عدد بذر در هر يترىديش بر روى كاغذ

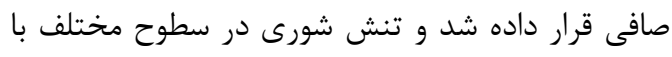

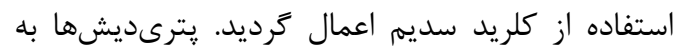

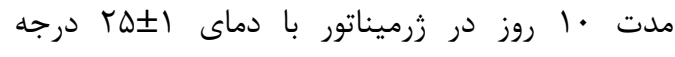
سانتى بذرهاى جوانهزده شمارش شدند (معصومى زواريان و ورئ

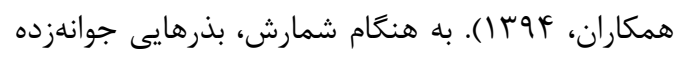

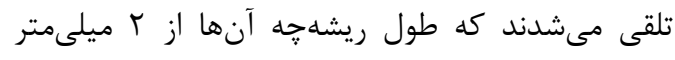

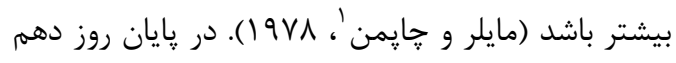

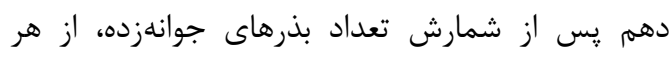
يترىديش ل عدد گياهجه بهصورت تصادفى انتخاب و

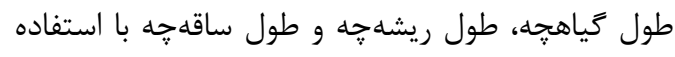
از خط كش مدرج و وزن خشك گياهجه (خشك كردن

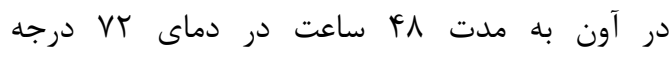
سانتى

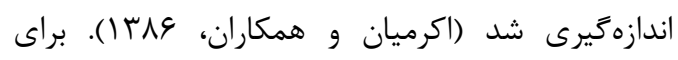
محاسبه درصد جوانهزنى از رابطه I (ايستا؟، • • • (Y)،

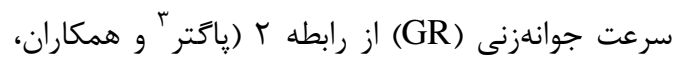

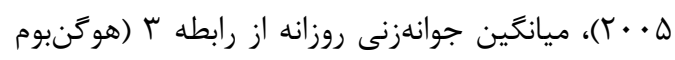

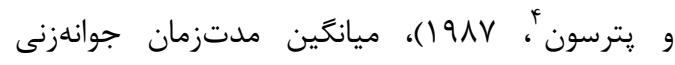
از رابطه \& (MGT) جوانهنى (GC) نيز از رابطه ه (اسكات "و همكاران،

\footnotetext{
${ }^{1}$ Miller and Chapman,

2 ISTA

${ }^{3}$ Pagter

${ }^{4}$ Hoogenboom and Peterson

${ }^{5}$ Ellis and Roberts

${ }^{6} \mathrm{Scott}$
} 
در طول موج • • ب نانومتر به مدت يك دقيقه با دستكاه اسيكتروفوتومتر قرائت شد. براى تبديل كاتالاز، عدد به

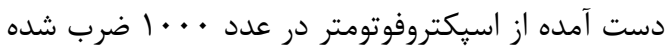

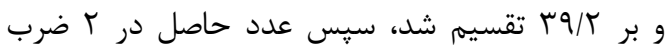

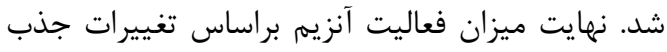

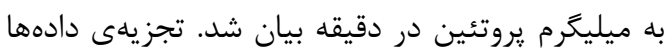

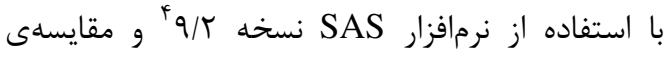

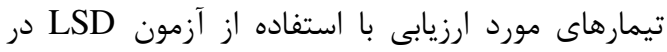
سطح احتمال ه درصد انجام شد.

نتايج و بحث درصد و سرعت جوانهزنى

بر اساس نتايج تجزيه واريانس، اثر سطوح تنش

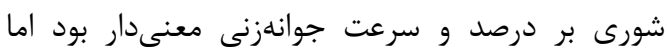

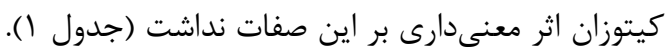
بيشترين درصد و سرعت جوانهزنى در تيمار شاهد (عدم

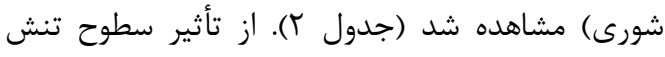
شورى بر درصد و سرعت جوانهزنى مشخص شد كه تا تنش شورى ^ دسىزيمنس بر متر تفاوت معنىدارى

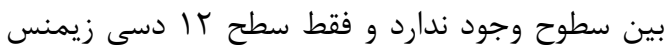
بر متر تنش شورى كاهش معنى دارى نشان داد (جدول

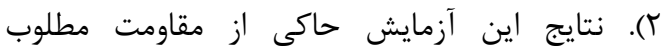
ماريتيغال از حيث درصد و سرعت جوانهزنى نسبت بـ ارنه

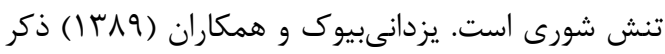
كردند كه ويزگكىهاى جوانهزنى كياه دارويى ماريتيغال

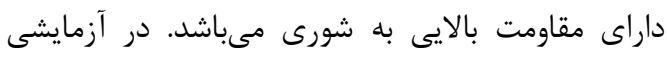

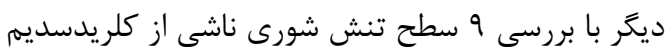

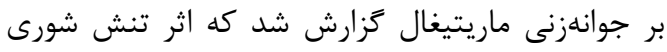

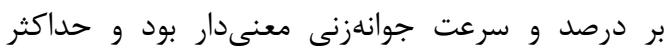

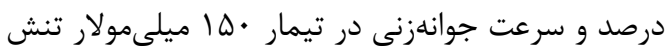
شورى مشاهده كرديد كه نشاندهندهى اين مطلب است

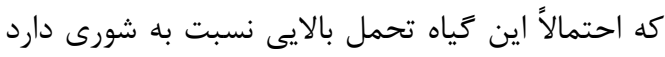

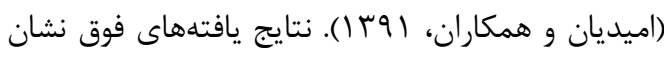

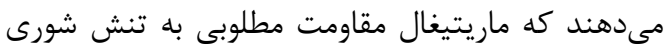

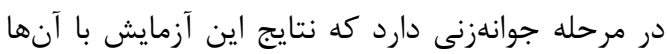
همخوانى داشت.

${ }^{4}$ SAS 9.2

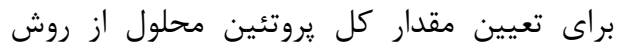

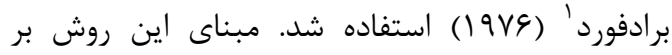
اساس اتصال رنگ كوماكسى بريانت بلو G250 موجود

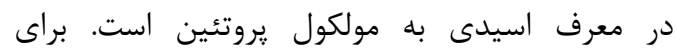

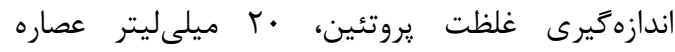
استخراجشده را در •^ ميكروليتر بافر استخراج رقيق

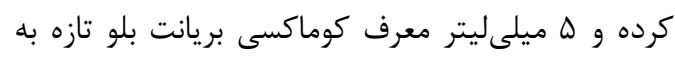

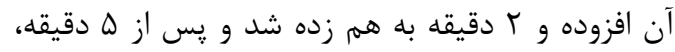

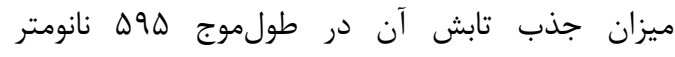

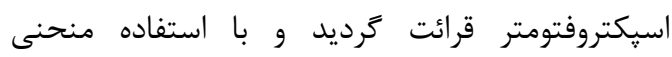

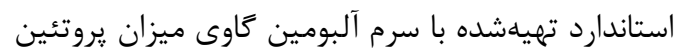
در نمونه محاسبه شد.

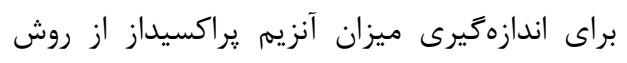

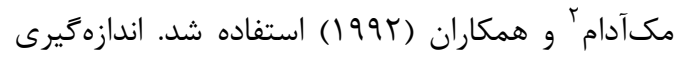

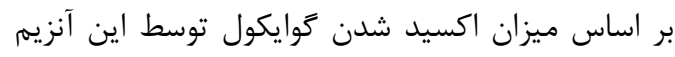

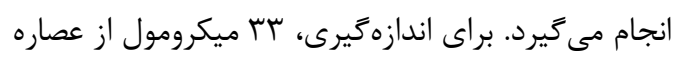

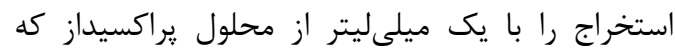
شامل با ميلىمولار توايكول، ه ميلىمولار يراكسيد

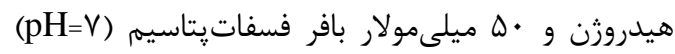

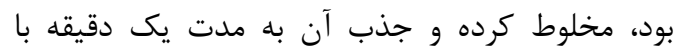

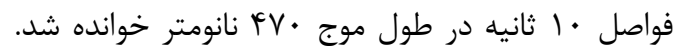

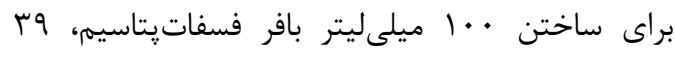

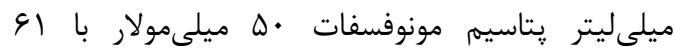

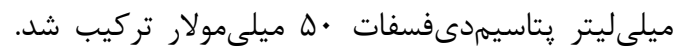

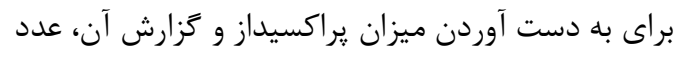

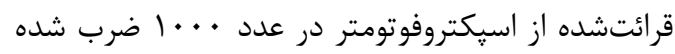

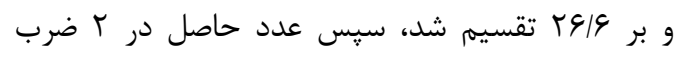

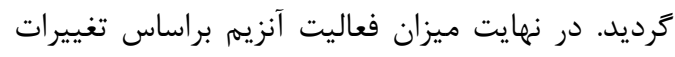
جذب به ميليكرم يروتئين در دقيقه بيان شد فردان

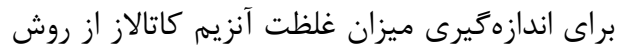

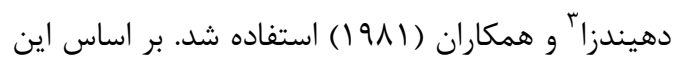

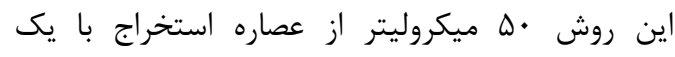

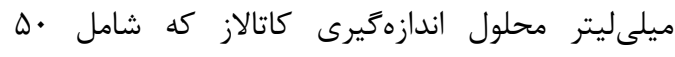

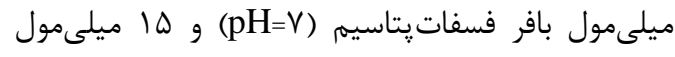
يراكسيد هيدروزن بود مخلوط كرديد. سيس جذب فئب آن

\footnotetext{
${ }^{1}$ Bradford

${ }^{2}$ Mac-Adam

${ }^{3}$ Dhindsa
} 
مجله يزوهش هاى بذر ايران/ سال سوم/ شماره دوم/ هوسا

\begin{tabular}{|c|c|c|c|c|c|c|c|c|c|c|c|}
\hline \multicolumn{12}{|c|}{ جدول ا- تجزيه واريانس تأثير سطوح مختلف كيتوزان بر شاخصهاى جوانهزنى گياه دارويى ماريتيغال تحت تنش شورى } \\
\hline \multicolumn{10}{|c|}{ ميانگين مربعات } & \multirow[b]{2}{*}{ آزادى درجه } & \multirow[b]{2}{*}{ تغنييرات } \\
\hline بيوماس & كياهجه & ساقه קه & ريشه & شنيه بذر طولى & شاخص بذر بنيه & جوانهزنى ستى & ضوانهزنى & جتوسط زمان & جوانهزنى & & \\
\hline $\begin{array}{c}V \ll q / r \Delta \\
n s\end{array}$ & $1 / A r^{\mathrm{ns}}$ & $1 / 9 V^{*}$ & $1 / \wedge F^{\mathrm{ns}}$ & rFIqfY ${ }^{\mathrm{ns}}$ & $T Y N / T Q^{*}$ & $\cdot / \cdot \Lambda^{\mathrm{ns}}$ & $r+1 / A r^{*}$ & $\cdot / \cdot 1^{\mathrm{ns}}$ & $r \cdot / V r^{\text {ns }}$ & r & 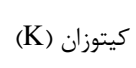 \\
\hline एद9 / / & $r \cdot N / F r^{*}$ & $19 / 1 r^{m * *}$ & $119 / 9^{* * *}$ & rFr.rI91* & 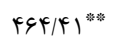 & $\cdot / A T^{* *: *}$ & $\mathrm{Vq} / \mathrm{V}^{\text {v*: }}$ & $\cdot 1 \cdot 9^{* * * *}$ & $19 \mathrm{~F} / \mathrm{Ar}$ & r & شورى (S) \\
\hline $\begin{array}{c}\text { GKG/FT } \\
\mathrm{ns}\end{array}$ & $r / 9 Y^{\mathrm{ns}}$ & $\cdot / r^{\mathrm{ns}}$ & $r / r V^{n s}$ & 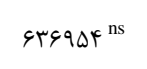 & $\Delta \Lambda / 9 \Delta^{\mathrm{ns}}$ & $\cdot / \cdot \wedge^{\mathrm{ns}}$ & $\mid \varepsilon V / \mathrm{F}^{\mathrm{ns}}$ & $\cdot / \cdot 1^{\mathrm{ns}}$ & $\mathrm{rq} / 9 \Lambda^{\mathrm{ns}}$ & ir & $\mathrm{K} \times \mathrm{S}$ \\
\hline $1 \cdot \tau \cdot / 1 \Delta \Delta$ & $\Delta / 9 \Lambda$ & $\cdot / \& V$ & $f / v q$ & $9 M \Lambda I Q F$ & ११/• & $\cdot / \cdot \Lambda$ & $\Lambda 9 / \Delta T$ & $.1 \cdot 1$ & $G \pi / V \Delta$ & f. & آزمايشى اشتباه \\
\hline$\Delta / / F$ & $r r / 4 q$ & $r|/ 9|$ & $r \cdot / r \Delta$ & $I N / D F$ & $5 \cdot 1 \cdot 9$ & $\Delta / 9)$ & $9 / 91$ & 1.1. & $9 / \pi r$ & (درصد) & ضريب تغييرات \\
\hline
\end{tabular}

جدول r- مقايسه تأثير سطوح مختلف تنش شورى بر ميانكين شاخصهاى جوانهزنى بذر گياه دارويى ماريتيغال

\begin{tabular}{|c|c|c|c|c|c|c|c|c|c|c|}
\hline (ميلى كرم) & 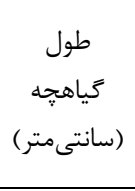 & 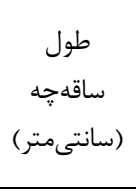 & (سانتىمتر) & طولى بنيه & شذاخص بذر بنيه & (بذر درانهزنى & ضوانهزنى & جوانه زمان & جوانهزنى درصد & سطوح شورى \\
\hline qr.।19a & $\mid \& / \xi \wedge a$ & $\mathrm{r} / 9 \Delta \mathrm{a}$ & $1 . / 9 \mathrm{ra}$ & Irquffa & $\Delta s / \cdot r \mathrm{a}$ & $\Delta / T \vee a$ & $1 \cdot \Delta / \mathbb{F}^{\mathrm{c}} \mathrm{a}$ & $\cdot / 9 \Delta \mathrm{c}$ & $9.199 a$ & صفر (شاهد) \\
\hline słe/sVa & $11 / \wedge 9 b$ & $f / f v a$ & $V / f r b$ & $1 \cdot f \gamma \cdot \wedge b$ & QI/rrab & $\Delta / 1 / \mathrm{a}$ & $1 \cdot r / \& \mathrm{rab}$ &.$/ 99 b c$ & $\Lambda f / \& \& a b$ & q \\
\hline $419 / \cdot \mathrm{Vb}$ & $q / \cdot \vee c$ & r/Vrb & $q / \pi c b$ & VAIYAC & $\hat{\imath} \wedge / \cdots b c$ & $\Delta / \cdot \varphi \mathrm{ab}$ & $a \xi / r \mathrm{fb}$ & $1 / \cdot c b$ & $\wedge \mathrm{N} / \cdots \mathrm{ab}$ & $\wedge$ \\
\hline$\Leftrightarrow 1 \cdot / 4 s b$ & $4 / \cdots \mathrm{d}$ & l/AFc & $\varphi / l \Delta c$ & $p q q \cdot \wedge d$ & FY/AIC & $\mathrm{f} / \Lambda \Leftrightarrow \mathrm{b}$ & $\wedge 9 / \cdot \wedge c$ & l/ ra & $\Lambda r / \Delta \cdot b$ & ir \\
\hline
\end{tabular}

يافتههاى ساير محققان نيز حاكى از آن است كه

ميانگين زمان جوانهزنى در كياه ذرت بهطور معنىدارى

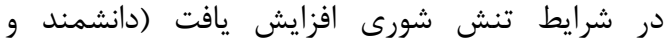

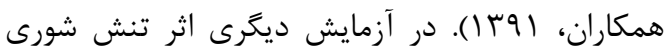
كلريد سديمى بر ميانگين مدتزمان جوانهزنى معنى دار

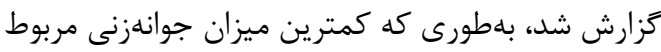

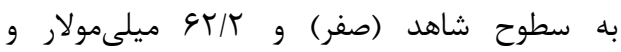
بيشترين ميزان آن مربوط به سطح شورى ميلىمولار بوده است (فتحى اميرخيز و همكاران،

(I) (1)

بذرهاى براى آغاز فعاليتهاى خود و ش شروع جوانهزنى نياز به آب كافى دارند. اگر بذر نتواند بهاندازيى كافى آب جذب كند يا جذب آب به كندى صورت گيرد، فعاليتهاى داخل بذر نيز بهكندى صورت گرفته و

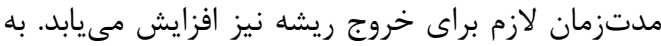
نظر مىرسد در جوانهزنى تحت تنش شورى و خشكى به
بايبوردى و طباطبايى' (9 . . ( بيان داشتند كه كاهش درصد و سرعت جوانهزنى در شرايط تنش شورى با كاهش جذب آب توسط بذر در مرحلهى آبخيرى و تورزسانس در ارتباط است.

\section{ميانگَين مدت زمان جوانهزنى}

نتيجه تجزيه واريانس نشان داد كه اثر تنش شورى بر ميانگين زمان جوانهزنى معنى دار بود اما كيتوزان اثر

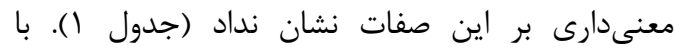
افزايش غلظت شورى، ميانگين زمان جوانهزنى افزايش يافت، بلهطورى كه بيشترين مقدار مربوط سطح شورى Y| دسىزيمنس بر متر (T//

$$
\text { سطوح شورى تفاوت معنى دارى داشت (جدول r). }
$$

\footnotetext{
${ }^{1}$ Bybordi and Tabatabaei
} 


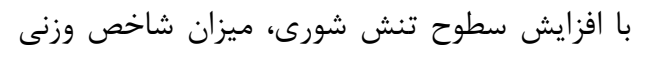
بنيه بذر كاهش يافت، بهطورى كه بيشترين ميانكين اين

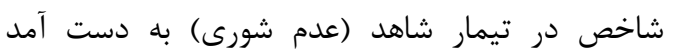

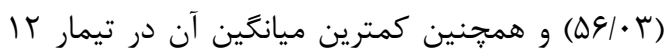

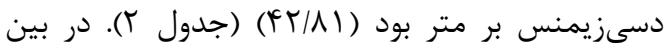
سطوح مختلف كيتوزان بيشترين مقدار شاخص وزنى داري

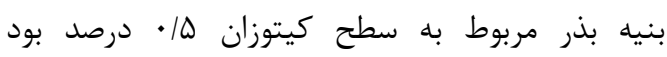
(QV/19)

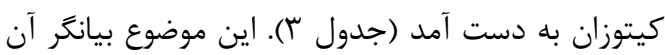

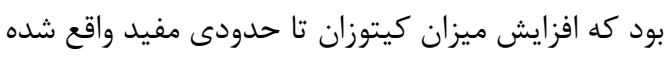

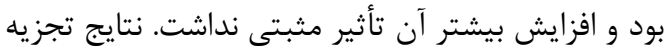
واريانس نشان داد كه اثر شورى بر صفت شاخص طولى ناني بنيه بذر معنى دار بود (جدول (). با افزايش سطح شورى از ميزان شاخص طولى بنيه بذر كاسته شد. بهطورى كه بيشترين مقدار مربوط به اين صفت در تيمار شاهد (عدم

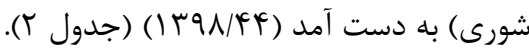

طول ريشه بر اساس نتايج تجزيه واريانس، اثر تنش شورى بر

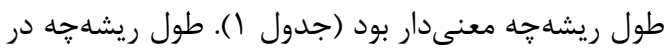

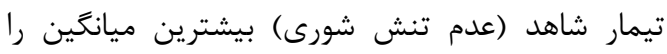

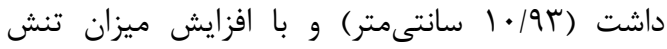
شورى اين ميانكَين كاهش نشان داد، بلهطورى كه

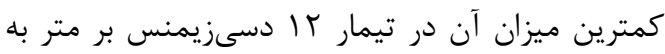

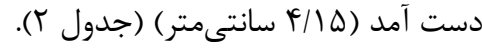

جدول r- مقايسه تأثير سطوح مختلف كيتوزان بر ميانكَين شاخصهاى جوانهزنى بذر كَياه دارويى ماريتيغال

\begin{tabular}{|c|c|c|c|}
\hline طول ساقهُ & شنيه بذر وزنى & جروانهزنى & $\begin{array}{c}\text { سطوح كيتوزان } \\
\text { (درصد) }\end{array}$ \\
\hline$r / \Lambda) a$ & $\Delta \cdot / r \mid a b$ & $\begin{array}{l}9 / / 94 \\
a b\end{array}$ & صفر (شاهد) \\
\hline$r / \Lambda \Delta \mathrm{b}$ & $\nLeftarrow \varepsilon / 91 b$ & $q \Delta / N T b$ & $\cdot \pi \Delta$ \\
\hline$r / r \wedge a b$ & $\Delta V / / 9 \mathrm{a}$ & $\begin{array}{c}1 \cdot 0 / 9 \Lambda \\
a\end{array}$ & $\cdot / \Delta$ \\
\hline$r / .4 b$ & $\varepsilon \& / 11 \mathrm{~b}$ & $q \Delta / A \cdot b$ & $\cdot / N \Delta$ \\
\hline$r / .1 \mathrm{~b}$ & $F \vee / r \wedge b$ & $q D / F T b$ & 1 \\
\hline
\end{tabular}

اعداد با حروف مشابه در هر ستون بر اساس آزمون PSD اختلاف معنى دارى ندارد.
دليل افت يتانسيل اسمزى، جذب آب مختل شده و در

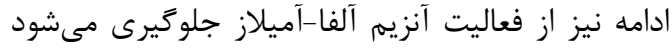

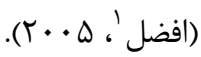

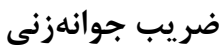
تأثير كيتوزان و تنش شورى بر ضريب جوانهزنى به إنه

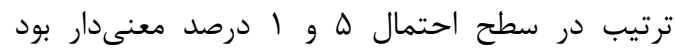

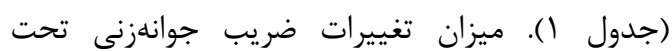
تيمارهاى كيتوزان بهَّونهاى بود كه در سطح ها ه • درصد

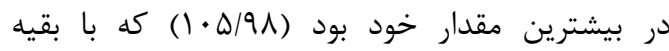

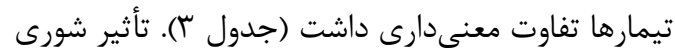
بر ضريب جوانهزنى نيز طورى بود كه در تيمار شاهد

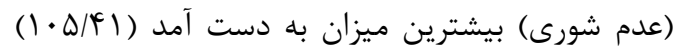

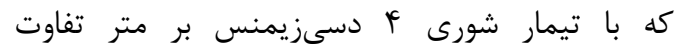

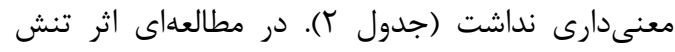

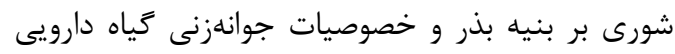

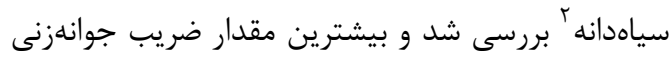
در تيمار شاهد (عدم تنش) مشاهده شد و با افزايش

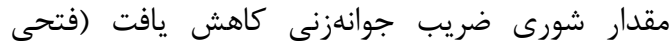

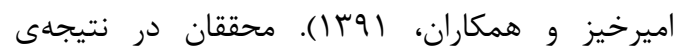

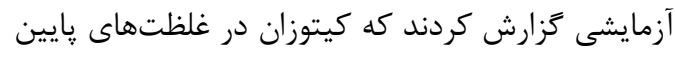

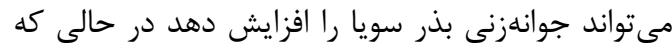

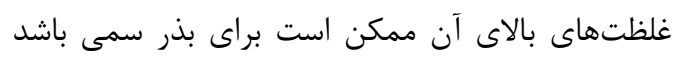

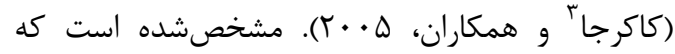

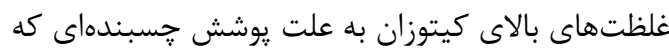

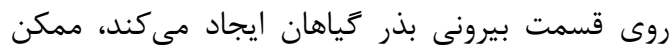
است سبب جلوكيرى از جذب آب توسط بذر شون شود

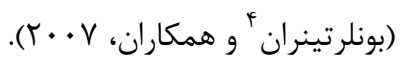

شاخص وزنى و طولى بنيه بذر نتيجه تجزيه واريانس نشان داد كه تأثير كيتوزان و و بند تنش شورى بر شاخص وزنى بنيه بذر به ترتيب در سطح

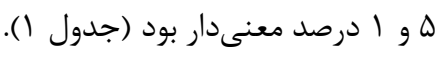

\footnotetext{
${ }^{1}$ Afzal

${ }^{2}$ Nigella sativa $\mathrm{L}$.

${ }^{3}$ Kukreja

${ }^{4}$ Boonlertnirun
} 


$$
\begin{aligned}
& \text { سانتىمتر در يتانسيل اسمزى ه/ - مخاياسكال رسيد } \\
& \text { (مصطفوى و حيدريان، اوبا). }
\end{aligned}
$$

\section{طول گَياهجه}

نتايج تجزيه واريانس نشان داد كه اثر تنش شورى بر صفت طول گياهجه در سطح ا درصد معنى (جدول (1). طول گياهجه در تيمار شاهد (عدم تنش شورى) در مقايسه با ساير تيمارها، در بيشترين ميزان خود بود (Y/AN| طول گياهجه كاهش نشان داد (جدول r). از اين مطلب

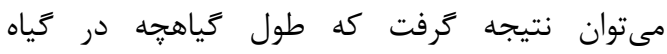
ماريتيغال بهشدت تحت تأثير شورى قرار مى مىيرد. فلاحى و همكاران (INVV) در بررسى روى گياه دارويى

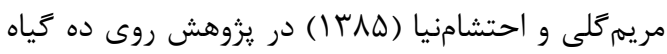
دارويى گزارش كردند كه با افزايش سطح تنش شورى،

طول گياهجه كاهش مىيابد.

\section{بيوماس كل}

نتايج تجزيه واريانس نشان داد كه اثر شورى بر

بيوماس كل معنىدار بود (جدول ()). با افزايش سطح

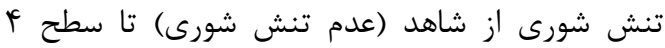
دسىزيمنس بر متر، ميزان بيوماس كل افزايش يافت و به بيشترين مقدار خود رسيد (99/A9 ميلى

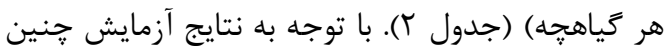
استدلال مىشود كه براى توليد بيوماس زياد در كياه

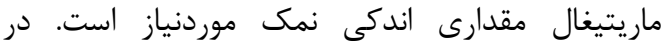
آزمايشى با افزايش سطح تنش شورى، ميزان بيوماس ماس مارئ كل در زياهجه گُندم كاهش يافت، بلهورى كه بيشترين ميزان بيوماس در سطح شاهد (عدم تنش) و كمترين ميزان آن در بالاترين سطح تنش شورى به دست آدر سيط

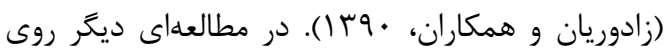
زياه برنج زَارش شد كه بيشترين ميزان بيوماس كل

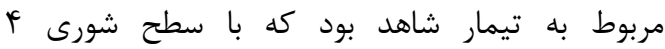

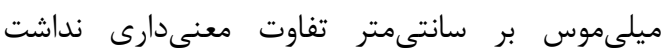

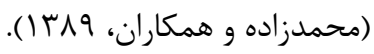

با توجه به نتايج آزمايش، طول ريشهجه نسبت به

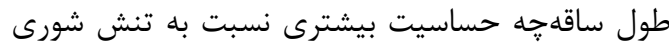
نشان داد. محققين با بررسى اثر تنش شورى بر طول

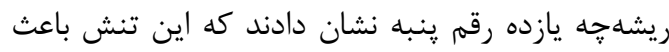
كاهش طول ريشهجه مىشود و اين صفت نسبت به طول ساقه كه ريشه جه حساسترين قسمت زياه نسبت به تنش

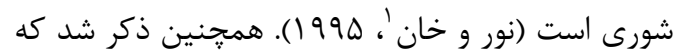
تحت تنش شورى، عملكرد هورمون سيتوكينين در

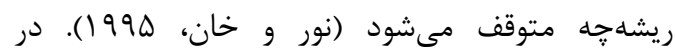

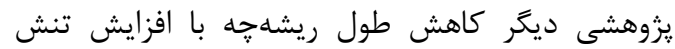

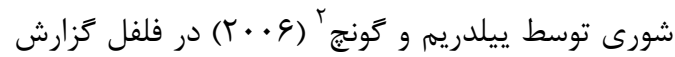
شد. همجنين در تحقيقى ديگر كاهش طول ريشه ساقه گه در نخودفرنكى تحت تنش شورى گزارش شد

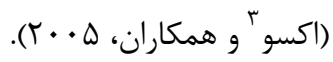

\section{طول ساقه}

نتايج تجزيه واريانس نشان داد كه تأثير تنش

شورى و كيتوزان بر صفت طول ساقهجه به ترتيب در سطح احتمال I و ه در صد معنى دار بود (جدول ()).

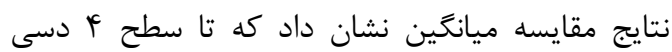
زيمنس بر متر تنش شورى، ميانگين طول ساقه

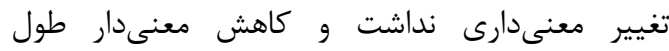
ساقه جه بعد از اين سطح تنش شورى اتفاق افتاد (جدول ץ). اين مطلب بيانگر آن است كه صفت طول ساقهجه تا حدودى مىتواند شورى را تحمل كند. تأثير كيتوزان نيز بهُّونهاى بود كه در تيمار شاهد (عدم استفاده از كيتوزان)، طول ساقهجه بيشترين ميانگين را داشت

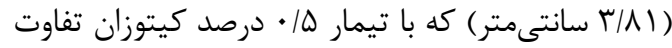
معنىدارى نشان نداد (جدول ب). با توجه به نتايج آزمايش مىتوان جنين نتيجه ميرى كرد كه استفاده از كيتوزان براى تعديل اثر شورى روى صفت طول گياهجه بىتأثير بوده است. در آزمايشى بر روى كي گياه آفتابگردان

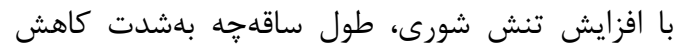

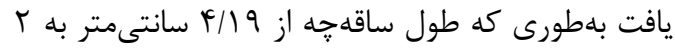

\footnotetext{
${ }^{1}$ Noor and Khan

${ }^{2}$ Yildirim and Guvenc

${ }^{3} \mathrm{Oksu}$
} 
شد بلهورى كه بيشترين مقدار در تيمار شاهد (عدم

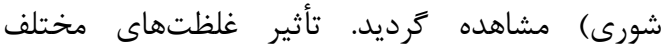
كيتوزان براى مقابله با اثر تنش شورى بر اين صفردي

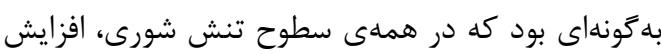
غلظت كيتوزان تا سطح ه/· • درصد، موجب افزايش ميزان يروتئين كل كرديد و در غلظتهاى بالاتر منجر

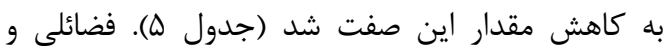

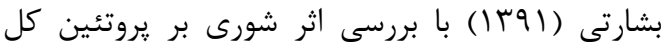
يونجه كَزارش كردند كه با افزايش شدت تنش التش شورى

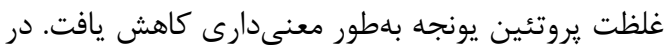
يُوهشى ديخر محققان تزارش كردند شورى موجب كاهش يروتئين كل در جند گَونه از شنبليله كرديد

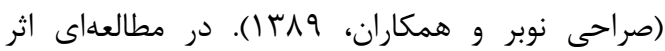

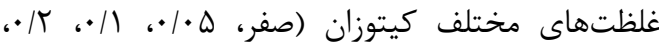

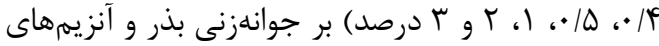

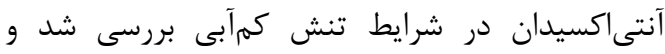

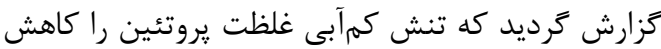
مىدهد، در حالى كه پيش تيمار بذرها با غلظت

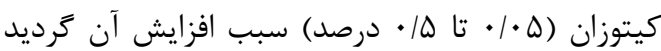

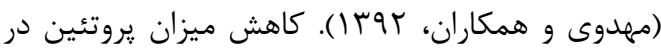
شرايط تنش شورى را مىتوان هم به تخريب يروتئين و

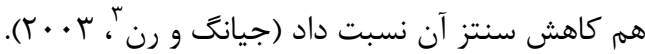

\section{فعاليت آنزيمهاى كاتالاز و يراكسيداز}

نتايج تجزيه واريانس نشان داد كه اثر تنش شورى، كيتوزان و اثر متقابل شورى در كيتوزان بر غلظت

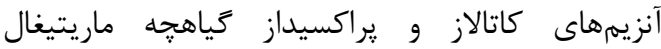
معنى دار بود (جدول \&ٔ). نتايج مقايسه ميانگين نشان داد

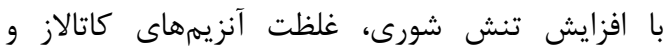
يراكسيداز افزايش يافتند. در بين غلظتهاى مختلف

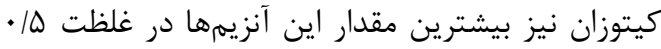
درصد به دست آمد. همجنين در شرايط بدون تنش آنش (عدم شورى) ميزان اين آنزيمها در غلطت ف/ • درصد درد

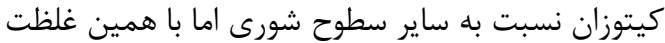

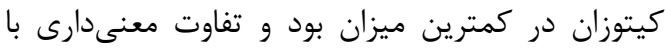
آنها داشت (جدول هان در).

\footnotetext{
${ }^{3}$ Jiang and Ren
}

كلروفيل كل

نتايج تجزيه واريانس نشان داد كه اثر تنش شورى، كيتوزان و همجنين اثر متقابل شورى در كيتوزان بر

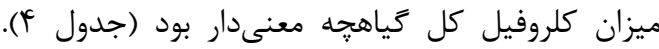

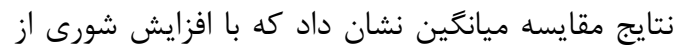
ميزان كلروفيل كل كياهجه ماريتيغال كاسته شد و تأثير كيتوزان براى تعديل اثر شورى بهَّونهاى بود كه تا حدودى افزايش غلظت آن مؤثر بود، ولى افزايش بيش آن ازئ حد آن باعث كاهش ميزان كلروفيل كل در اين كياه كرديد (جدول ها). بهطورى كه در اين آزمايش بيشترين مقدار كلروفيل كل كياهحه در سطح شاهد (عدم تنش شورى) و غلظت هاء• درصد كيتوزان به دست آمد داهد

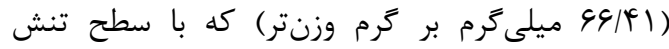

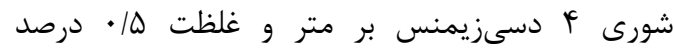

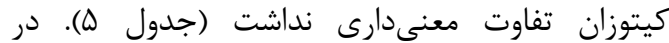

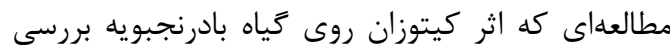

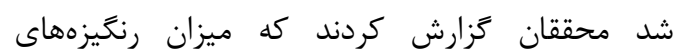
كلروفيلى و كاروتنوئيد تحت تأثير كيتوزان افزايش

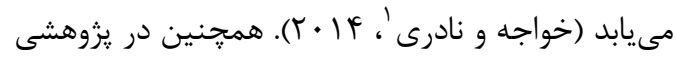
ديخر با بررسى اثر غلظتهاى مختلف كيتوزان بر كياه

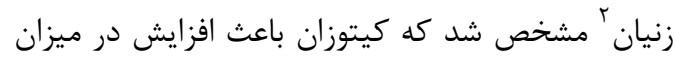
كلروفيل a و a در اين كياه مىشود (نادرى و همكاران،

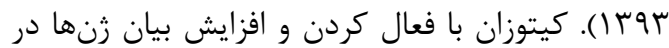
مسير بيوسنتزى توليد كلروفيل بهخوبى عمل كردها و ورئ ميزان كلروفيل را افزايش مىدهد (امامىبيستكانى و

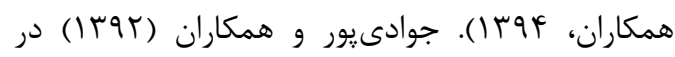
ارزيابى كلروفيل برك ارقام كلرنگ تحت تنش شورى كزارش كردند كه شورى باعث كاهش كلروفيل در همه

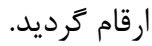

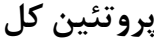

نتايج تجزيه واريانس نشان داد كه برهمكنش

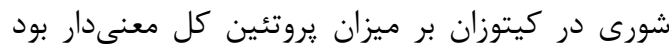

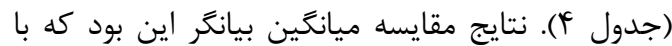
افزايش سطح تنش شورى از ميزان يروتئين كل كاسته

\footnotetext{
${ }^{1}$ Khajeh and Naderi

${ }^{2}$ Trachyspermum ammi $\mathrm{L}$.
} 
مجله يزوهشهاى بذر ايران/ سال سوم/ شماره دوم/ هوسا

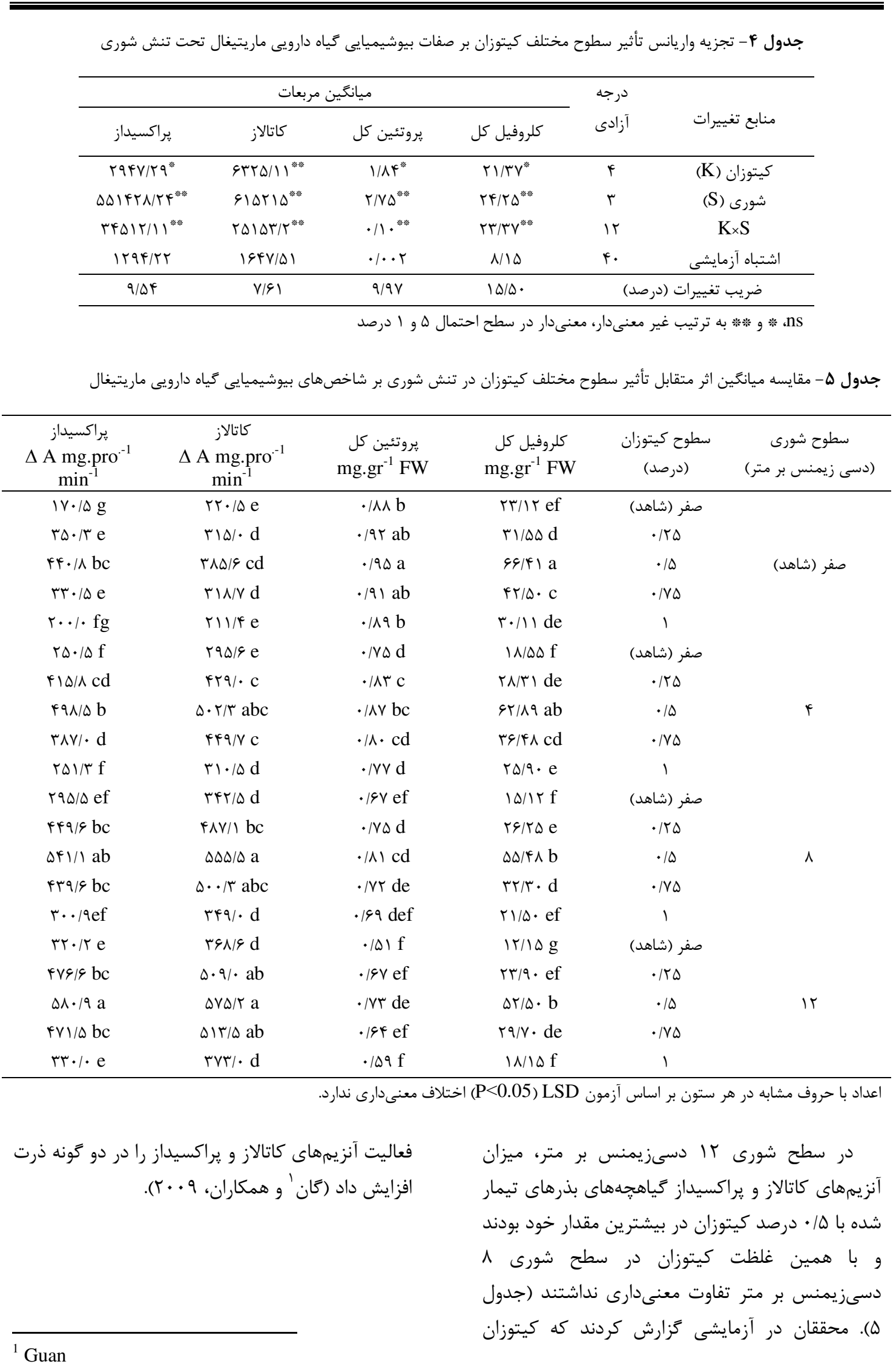


مجله يزوهشهاى بذر ايران/ سال سوم/ شماره دوم/ هو سا

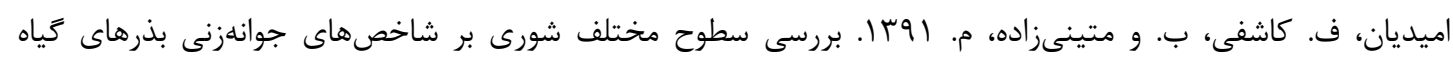
دارويى ماريتيغال (.Silybium marianum L). همايش ملى محيطزيست و توليدات كياهى، و صفحه.

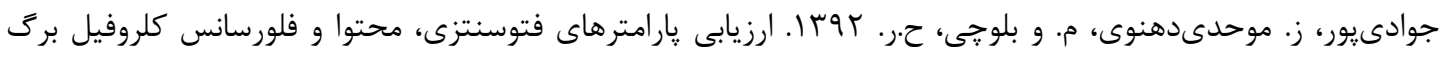

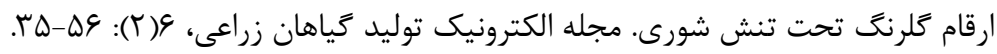

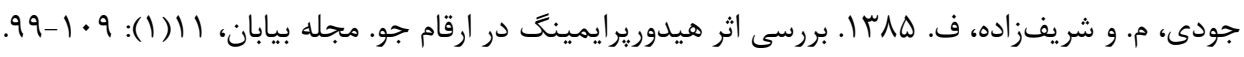

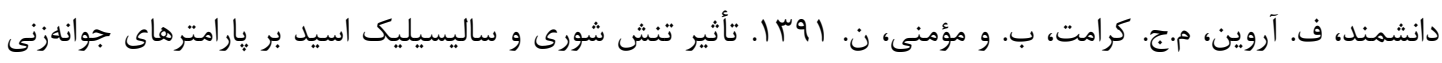

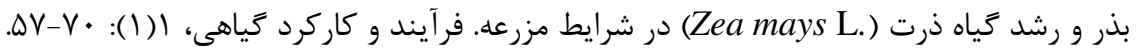
زادوريان، گ. خدارحمى، م. امينى، ا. و مصطفوى، خ. • وج ا. بررسى تأثير تنش شورى ناشى از كلريدسديم بر بيوماس ارقام

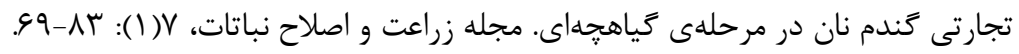

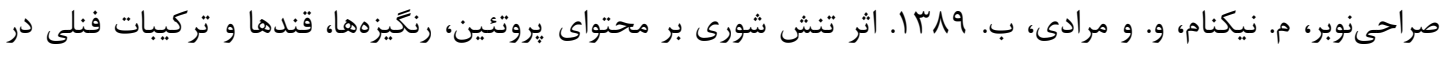

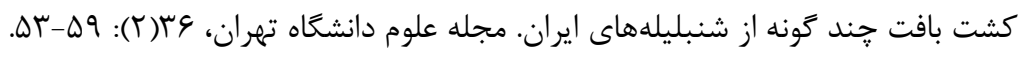

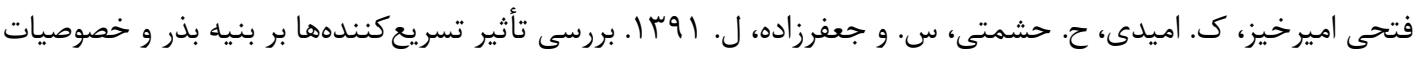

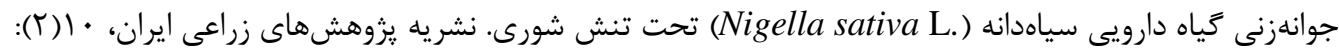
. (

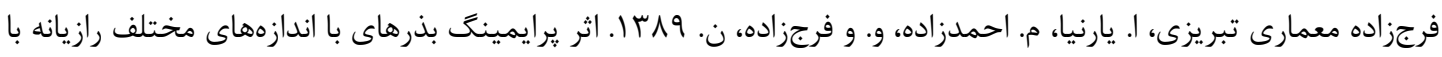

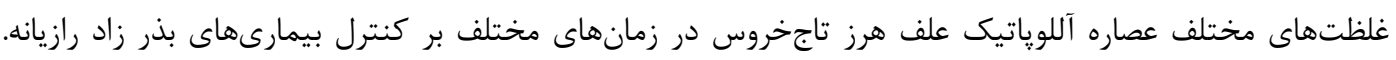

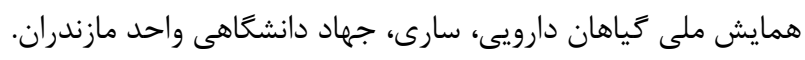

فضائلى، ع. و بشارتى، ح. أوبا. تأثير شورى بر برخى شاخصهاى رشد و يروتئين كل يونجه تلقيح شده با جدايههاى

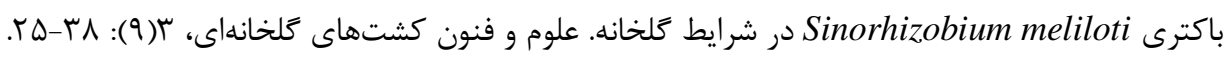

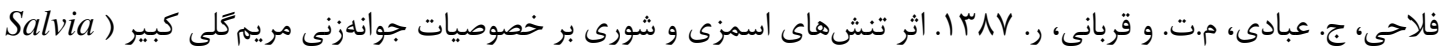

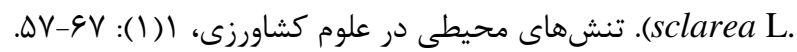

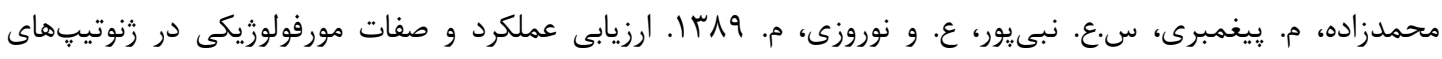

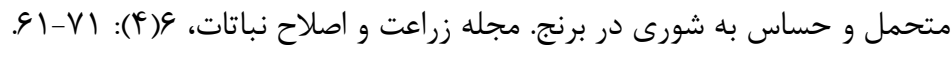

مصطفوى، خُ و حيدريان، ع. أوبا. بررسى تأثير تنش شورى بر جوانهزنى و شاخصهاى آن در جهار رقهم كياه آفتابكردان.

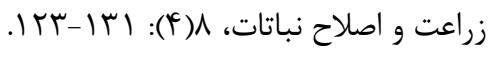

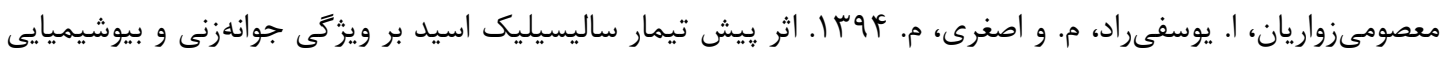

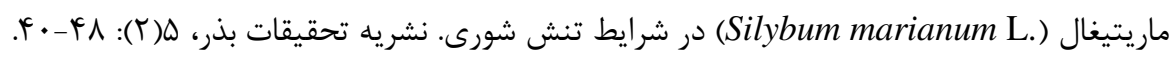

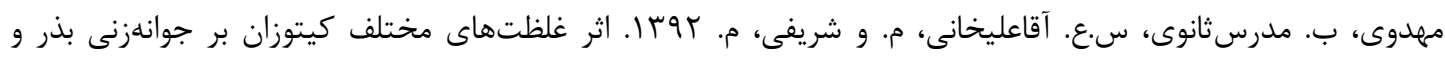

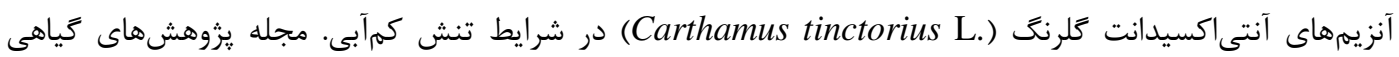

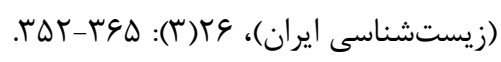

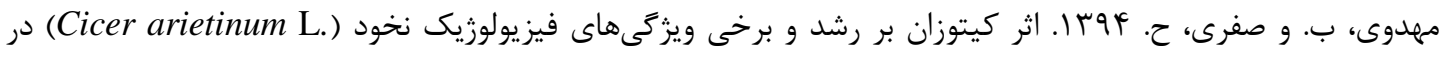

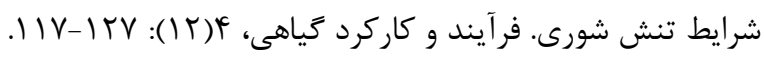


عقيقى شاهوردى و همكاران: تأثير كيتوزان بر جوانهزنى و صفات بيوشيميايى گياهجه ماريتيغال...

$$
\begin{aligned}
& \text { نادرى، ص. فاخرى، ب.ع. و بهرامى، م. بوجا ا. اثركذارى كيتوزان بر برخى شاخصهاى فيزيولوزيك و بيوشيميايى كياه }
\end{aligned}
$$

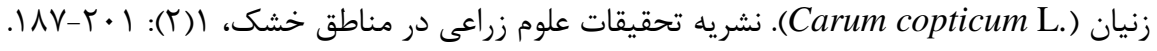

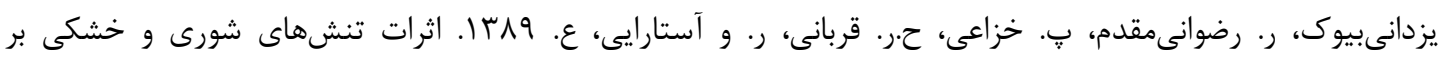

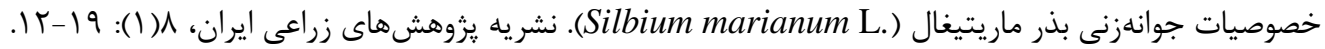

Afzal, I. 2005. Seed enhancement to induced salt tolerance in wheat (Triticum aestivum L.). Ph.D. Thesis, Agriculture University of Faisalabad, Pakistan.

Arnon, A.N. 1967. Method of extraction of chlorophyll in the plants. Agronomy Journal, 23: 112121.

Boonlertnirun, S., Sarabol, E.D., Meechoui, S., and Sooksathan, I. 2007. Drought recovery and grain yield potential of rice after chitosan application. Kasetsart Journal:Nature Science, 41: 1-6.

Bradford, M.M. 1976. A rapid and sensitive method for quantitation of microgram quantities of protein utilizing the principle of protein-dye binding. Analytical Biochemistry, 72(1-2): 248254.

Bybordi, A., and Tabatabaei, J. 2009. Effect of salinity stress on germination and seedling properties in canola (Brassica napus L.). Notulae Botanicae Horti Agrobotanici Cluj-Napoca, 37(2): 71-76.

Cho, M.H., No, H.K., and Prinyawiwatkal, W. 2008. Chitosan treatments after growth and selected quality of sunflower sprouts. Journal of Food Science, 73(1): 70-77.

Coma, V., Martial-Gros, A., Garreou, S., Copinet, A., Salin, F., and Deschamps, A. 2002. Edible antimicrobial films based on chitosan matrix. Journal of Food Science, 67(3): 1162-1169.

Dhindsa, R.H., Plumb-Dhindsa, R., and Thorpe, T.A. 1981. Leaf senescence correlated with increased level of membrane permeability, lipid peroxidation and decreased level of SOD and CAT. Journal of Experimental Botany, 32(1): 93-101.

Ellis, R.H., and Roberts, E.H. 1981. The quantification of ageing and survival in orthodox seeds. Seed Science and Technology, 9: 377-409.

Gornik, K., Grzesik, M., and Romanowska-Duda, B. 2008. The effect of chitosan on rooting of grapeving cutting and on subsequent plant growth under drought and temperature stress. Journal of Fruit and Ornamental Plant Research, 16: 333-343.

Guan, Y.J.J., Hu, X., Wang, J., and Shao, C.X. 2009. Seed priming with chitosan improves maize germination and seedling growth in relation to physiological changes under low temperature stress. Journal of Zhejiang University Science B, 10(6): 427-433.

Harish Prashanth, K.V., Dharmesh, S.M., Jagannatha Rao, K.S., and Tharanathan, R.N. 2007. Free radical-induced chitosan depolymerized products protect calf thymus DNA from oxidative damage. Carbohydrate Research, 342(2): 190-195.

Hoogenboom, G., and Peterson, C.M. 1987. Shoot growth rate of soybean as affected by drought stress. Agronomy Journal, 79(4): 598-607.

ISTA, 2010. International rules for seed testing. International seed testing association (ISTA).

Jiang, H.F., and Ren, X.P. 2003. The effect on SOD activity and protein content in groundnut leaves by drought stress. Zuo Wu Xue Bao, 30(2): 169-174.

Kader, M.A., and Jutzi, S.C. 2004. Effect of thermal and salt treatments during imbibition on germination seedling growth of sorghum (Sorghom bicolor L.) at 42/19. Journal of Agronomy and Crop Science, 190(1): 35-38. 
Kakreja, S., Nandval, A.S., Kumar, N., Sharma, S.K., Unvi, V., and Sharma, P.K. 2005. Plant water status, $\mathrm{H}_{2} \mathrm{O}_{2}$ scavenging enzymes, and ethylene evolution and membrane integrity of Cicer arietinum roots as affected by salinity. Biologia Plantarum, 49(2): 305-308.

Khajeh, H., and Naderi, S. 2014. The effect of chitosan on some antioxidant enzymes activity and biochemistry characterization in Melissa (Melissa officinalis). Research Journal of Crop Science in Arid Area, 1: 100-116.

Kowalski, B., Jimenez, F., Herrera, L., and Agramonet Penalver, D. 2006. Application of soluble chitosan in vitro and in the greenhouse to increase yield and seed quality of potato minitubers. Potato Research, 49(3): 167-176.

MacAdam, J.W., Nelson, R., and Sharp, E. 1992. Peroxidase activity in the leaf elongation zone of tall fescue. patial distribution of ionically bound peroxidase activity in genotypes differing in length of the elongation zone. Plant Physiology, 99(3): 872-878.

Mandal, S. 2010. Induction of phenolics, lignin and key defense enzymes in eggplant (Solanum melongena L.) roots in response to elicitors. African Journal of Biotechnology, 9: 8038-8047.

Miller, T.R., and Champan, S.R. 1978. Germination responses of three forage grasses to different concentration of six salts. Journal of Range Management, 31(2): 123-124.

Noor, M. E. H. E. R., and Khan, M. A. 1995. Factors an ecting germination of summer and winter seeds of Halopyrum mucronatum. under salt stress. Biology of Salt Tolerant Plants, 6: 51-58.

Oksu, G., Kaya, M.D., and Atak, M. 2005. Effects of salt and drought stresses on germination and seedling growth of pea (Pisum sativum L.). Turkish Journal of Agriculture and Forestry, 29(4): 237-242.

Pagter, M., Bragato, C., and Brix, H. 2005. Tolerance and physiological responses of (Phragmites australis to water deficit. Aquatic Botany, 81(4): 285-299.

Park, P.J., Je, J.Y., and Kim, S.K. 2004. Free radical scavenging activities of differently deacetylated chitosans using an ESR spectrometer. Carbohydrate Polymers, 55(1): 17-22.

Rauf, M., Munir, M., Hassan, M.U., Ahmad, M., and Afzal, M. 2007. Performance of wheat genotypes under osmotic stress at germination and early seedling growth stage. African Journal of Biotechnology, 6(8): 971-975.

Sairam, R.K., Rao, K.V., and Srivastava, G.C. 2002. Differential response of wheat genotypes to longterm salinity stress in relation to oxidative stress, Antioxidant active and osmolyte concentration. Plant Science, 163(5): 1037-1046.

Scott, S.J., James, R.A., and Williams, W.A. 1984. Review of data analysis methods for seed germination. Crop Science, 24(6): 1192-1199.

Serrano, R., Macia, F.C., and Moreno, V. 1999. Genetic engineering of salt and drought tolerance with regulatory genes. Science Horticulture, 78(1): 261-269.

Yildirim, E., and Guvenc, I. 2006. Salt tolerance of pepper cultivars during germination and seedling growth. Turkish Journal of Agriculture and Forestry, 30(5): 347-353. 


\title{
Effect of Chitosan on Seed Germination and Biochemical Traits of Milk Thistle (Silybum marianum L.) Seedling under Salt Stress
}

\author{
Mehdi Aghighi Shahverdi ${ }^{1, *}$, Heshmat Omidi ${ }^{2}$, Sayed Esmail Mousavi ${ }^{3}$ \\ ${ }^{1}$ PhD Students of Crop Physiology, Faculty of Agriculture, Shahed University, Tehran, Iran \\ ${ }^{2}$ Assistant Medicinal Plant Research Center and Shahed University, Tehran, Iran \\ ${ }^{3}$ M.Sc. Student Department of Agronomy, Shahed University, Tehran, Iran \\ "Corresponding author, E-mail address: m.aghighi@shahed.ac.ir
}

(Received: 29.04.2016 ; Accepted: 19.11.2016)

\begin{abstract}
For the purpose of evaluating the effect of chitosan on seed germination and some biochemical characteristics of the milk thistle herb in the conditions of salinity, an experiment was conducted as factorial in a completely randomized design (CRD) with three replications in the Laboratory of Seed Science and Technology of Shahed University, Tehran in 2015. Experimental factors comprised salinity levels $\left(0,4,8\right.$ and $\left.12 \mathrm{dS} . \mathrm{m}^{-1}\right)$ and different levels of Chitosan $(0,0.25,0.5,0.75$ and 1 percent). The results showed that salt stress reduced germination percentage, germination coefficient, germination speed, weight and length vigor index, radical, plumule and seedling length and total biomass and increased mean germination time. Seed priming with chitosan up to $0.5 \%$ concentration increased germination coefficient, weighted index vigor and plumule length. The highest amounts of total chlorophyll and total protein were obtained in seed priming with $0.5 \%$ chitosan levels in zero salinity level (control). By increasing salinity levels, the activity level of catalase and peroxidase increased, so that the highest level of the activity of these two enzymes was obtained in the salinity level of $12 \mathrm{dS} . \mathrm{m}^{-1}$ in pre-treatment with $0.5 \%$ Chitosan. The results showed that seed priming with chitosan of $0.5 \%$ could reduce harmful effects of salt stress on some traits of milk thistle seedlings and could even improve their growth.
\end{abstract}

Keywords: Catalase, Chlorophyll, Milk thistle, Peroxidase, Protein, Seed vigor 